\title{
Estimating phytoplankton productivity from light availability and biomass in the MERL mesocosms and Narragansett Bay
}

\author{
Aimee A. Keller \\ Marine Ecosystems Research Laboratory, Graduate School of Oceanography, University of Rhode Island, Kingston, Rhode \\ Island 02882-1197, USA
}

\begin{abstract}
Recent research has suggested that primary productivity in estuarine waters can be predicted as a function of phytoplankton biomass (chlorophyll a concentration) multiplied by light availability in the photic zone (photic depth times incident irradiance). The applicability of this function was confirmed using data from $1010{ }^{14} \mathrm{C}$ incubations (during 1978 to 1984) from 4 diverse mesocosm experiments and Narragansett Bay. For each experiment 70 to $80 \%$ of the variation in productivity was explained by the composite function. A regression equation developed from all experiments explained $82 \%$ of the variation in primary productivity and was not statistically different from a previously reported equation based on comparable data from 4 estuarine regions (North and South San Francisco Bay, Puget Sound, and New York Bight). Phytoplankton production was correlated with biomass alone on a seasonal basis (summer, $r=0.87$; non-summer, $r=0.77$ ), with chlorophyll-specific productivity higher during summer (June to September) than non-summer (October to May). The decline in the slope of the relation between production and biomass during non-summer periods corresponded to the seasonal switch from summer dominance by nanoplankton (primarily flagellates) to non-summer dominance by net plankton (primarily diatoms) and coincided with decreased light availability in the photic zone. Annual productivity was also highly correlated with the mean annual product of chlorophyll $a_{i}$ photic depth and incident light $(r=0.96)$.
\end{abstract}

\section{INTRODUCTION}

Attempts to determine the causal factors of temporal and spatial variability in estuarine phytoplankton productivity have focused primarily on nutrient or light availability (Riley 1967, Takahashi et al. 1973, Cadée \& Hegeman 1974, Malone 1976). Despite considerable effort it has not been possible to generalize about the relation between nutrient concentration and productivity (Boynton et al. 1982, Nixon \& Pilson 1983, Cole \& Cloern 1984). Part of the problem is due to the general availability of nutrients in estuaries. When nutrient levels exceed growth-limiting concentrations, short-term rates of phytoplankton growth as measured by ${ }^{14} \mathrm{C}$ uptake may appear independent of inorganic nutrient concentration (Nixon et al. 1986). Additionally, internal storage and rapid cycling and regeneration of nutrients may obscure a quantitative relationship when ambient nutrient concentration is used as an index of nutrient availability. High rates of production may then occur when measured nutrient concentrations are low. Because of these problems, no quantitative formulation describing a relation between nutrient concentration and primary productivity has been proposed for estuaries.

In turbid estuaries, biomass-specific production rates have long been associated with light (Flemer 1970. Malone 1976, Cadée 1978, Joint \& Pomroy 1981). More recently, researchers have shown that much of the variability in phytoplankton production is highly correlated with a composite factor, the product of phytoplankton biomass and light availability (Falkowski 1981, Cole \& Cloern 1984, 1987, Harding et al. 1986, Pennock \& Sharp 1986). Experimental work in largescale mesocosms at the Marine Ecosystem Research Laboratory (MERL) has concomittently established a strong linear relationship between nutrient loading level and phytoplankton biomass (Nixon \& Pilson 1983, Nixon et al. 1984, 1986, Keller 1987a). Given this relationship, the predictive ability of an empirical model including both light availability and biomass is not 
latter two. The bottles were incubated in their respective mesocosms at $0.1,0.5,1.0,2.5$, and $4.5 \mathrm{~m}$ with the dark bottle at $4.5 \mathrm{~m}$. Bay samples were incubated in a control mesocosm.

From March 1978 through May 1981 samples were incubated for $24 \mathrm{~h}$ from midmorning to midmorning. From June 1981, samples were incubated for $4 \mathrm{~h}$ around noon. After incubation samples were filtered through $25 \mathrm{~mm}$ Whatman $\mathrm{GF} / \mathrm{F}$ (or Gelman A/E) glass fiber filters at $<125 \mathrm{~mm} \mathrm{Hg}$. Filters were rinsed twice with $20 \mathrm{ml}$ filtered seawater to remove residual inorganic ${ }^{14} \mathrm{C}$ and placed in vials to which 3.5 or $10 \mathrm{ml}$ scintillation fluid was then added depending on vial size. Samples were shaken for $3 \mathrm{~h}$ to aid penetration of the filters and to allow degassing of inorganic ${ }^{14} \mathrm{C}$. Samples were then placed in the scintillation counter and counted after an $8 \mathrm{~h}$ dark-adaptation period.

Primary productivity at each depth was calculated following Strickland \& Parsons (1972) and converted to integral productivity over the photic zone by numerically integrating (trapezoidal rule) these values over the photic depth (up top $5 \mathrm{~m}$ ). Precision of bottle values was $\pm 10 \%$.
Houriy productivity measurements (June 1981 to September 1984) were converted to daily values by fitting the measured hourly rates and light data to the hyperbolic tangent equation (Platt \& Jassby 1976):

$$
P_{\mathrm{z}}=P_{\mathrm{m}} \tanh \left(\alpha I_{\mathrm{z}} / P_{\mathrm{m}}\right)
$$

where $P_{z}=$ measured hourly productivity at each of 5 depths ( $\mathrm{mg} \mathrm{C} \mathrm{m} \mathrm{C}^{-3} \mathrm{~h}^{-1}$ ); $I_{z}=$ - light available at each depth (Einst. $\mathrm{m}^{-2} \mathrm{~h}^{-1}$ ); $P_{\mathrm{m}}=$ maximum hourly production rate ( $\left.\mathrm{mgC} \mathrm{m}^{-3} \mathrm{~h}^{-1}\right)$; and $\alpha=$ initial slope of the photosynthesis-light curve (mg C Einst. ${ }^{-1} \mathrm{~m}^{-1}$ ). Eq. (1) was appropriate for fitting the data since photoinhibition was rarely observed during the MERL experiments. Using the fitted parameters ( $P_{\mathrm{m}}$ and $\alpha$ ), the measured hourly PAR, and the attenuation coefficients, hourly production rates $\left(P_{z}\right)$ were calculated for each hour of the day, integrated over the photic depth $\left(P_{\mathrm{h}}\right.$, $\left.\mathrm{mg} \mathrm{C} \mathrm{m}{ }^{-2} \mathrm{~h}^{-1}\right)$ and summed to give daily rates $\left(P_{\mathrm{d}}, \mathrm{mg}\right.$ $\mathrm{C} \mathrm{m}^{-2} \mathrm{~d}^{-1}$ ).

Model-derived daily productivity estimates approximate gross productivity since they were based on shortterm ${ }^{14} \mathrm{C}$ incubations (Harrison et al. 1985) and do not account for night-time respiratory loss. Comparison of

Table 2. Linear regression analyses of productivity $\left(P_{\mathrm{d}}, \mathrm{mg} \mathrm{C} \mathrm{m}^{-2} \mathrm{~d}^{-1}\right)$ versus the composite variable $\left(B Z_{\mathrm{p}} I_{10}\right)$ for $\mathrm{Narragansett}_{\mathrm{Bay}}$ the controls, and treatment mesocosms from the individual MERL experiments, March 1978 to September 1984; $m$ : slope; $b$ : intercept

\begin{tabular}{|c|c|c|c|c|}
\hline Experiment & $m( \pm S E)$ & $b( \pm \mathrm{SE})$ & $r^{2}$ & $n$ \\
\hline \multicolumn{5}{|c|}{ Oil addition and recovery } \\
\hline Bay & $0.98(0.12)$ & $230(102)$ & 0.64 & 28 \\
\hline Controls & $0.81(0.05)$ & $194(35)$ & 0.66 & 132 \\
\hline Treatments & $0.70(0.05)$ & $369(53)$ & 0.69 & 82 \\
\hline \multicolumn{5}{|l|}{ Sediment gradient } \\
\hline Bay & $1.04(0.09)$ & $97(49)$ & 0.78 & 41 \\
\hline Controls & $0.93(0.07)$ & $83(28)$ & 0.58 & 134 \\
\hline Treatments & $0.99(0.04)$ & $37(20)$ & 0.72 & 268 \\
\hline \multicolumn{5}{|l|}{ Nutrient addition } \\
\hline Controls & $0.66(0.05)$ & $109(28)$ & 0.81 & 75 \\
\hline Treatments & $0.66(0.04)$ & $454(91)$ & 0.81 & 151 \\
\hline \multicolumn{5}{|c|}{ Nutrient and sludge addition } \\
\hline Controls & $0.87(0.14)$ & $269(120)$ & 0.66 & 33 \\
\hline Treatments & $0.66(0.04)$ & $325(69)$ & 0.83 & 66 \\
\hline
\end{tabular}

Table 3. Linear regression analyses of productivity $\left(P_{\mathrm{d}}, \mathrm{mg} \mathrm{C} \mathrm{m}^{-2} \mathrm{~d}^{-1}\right)$ versus the composite variable $\left(B Z_{\mathrm{p}} I_{\mathrm{o}}\right)$ for the individual and combined MERL experiments, March 1978 to September 1984; $m$ : slope; $b$ : intercept

\begin{tabular}{|lrrrr|}
\hline Experiment & $m( \pm$ SE) & $b( \pm$ SE) & $r^{2}$ & $n$ \\
\hline Oil addition and recovery & $0.78(0.04)$ & $254(29)$ & 0.67 & 242 \\
Sediment gradient & $0.98(0.06)$ & $55(15)$ & 0.70 & 443 \\
Nutrient addition & $0.66(0.04)$ & $235(43)$ & 0.81 & 226 \\
Nutrient and sludge addition & $0.85(0.05)$ & $282(60)$ & 0.82 & 99 \\
Pooled experiments and Bay & $0.70(0.02)$ & $220(12)$ & 0.82 & 1010 \\
\hline
\end{tabular}




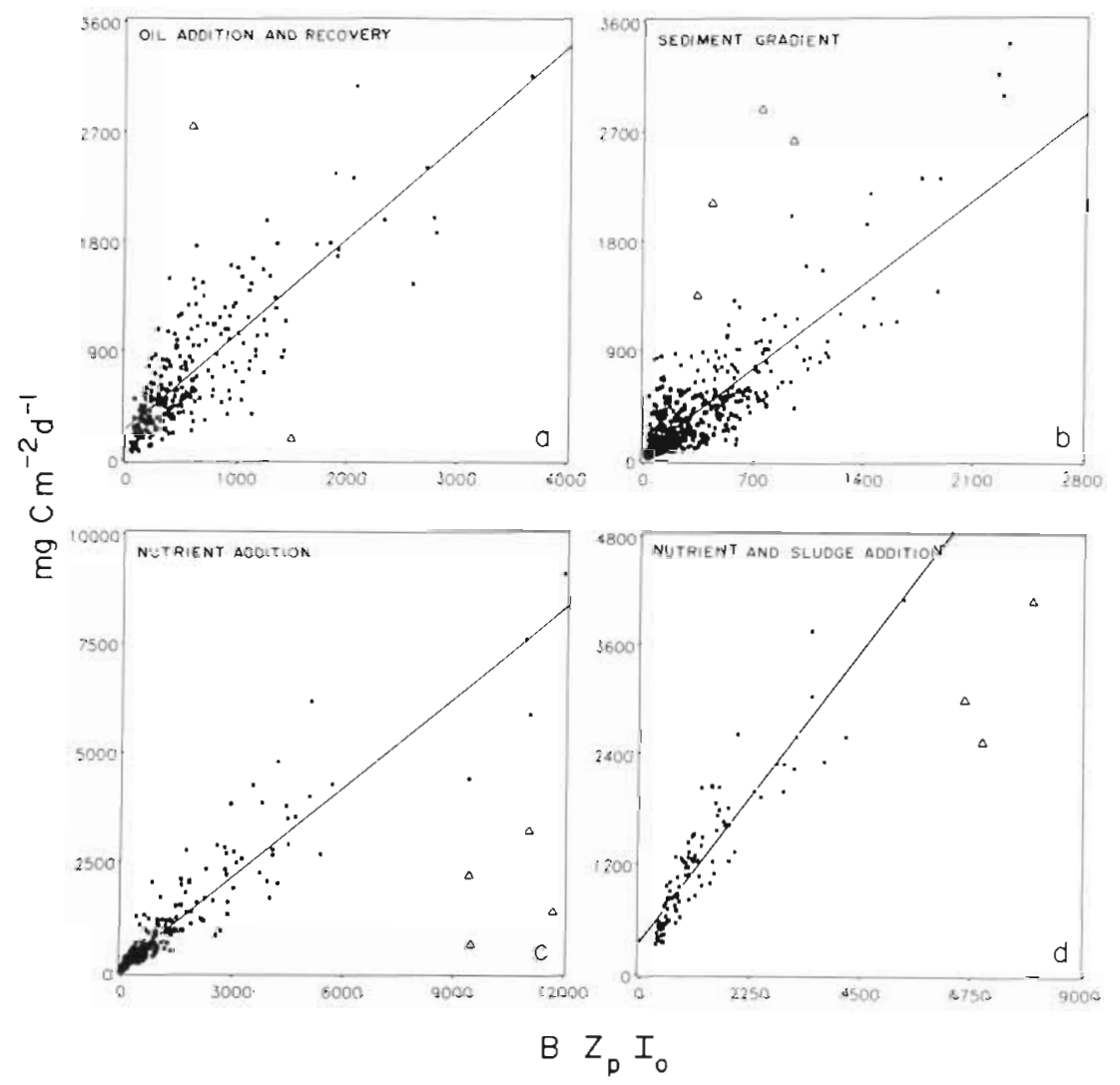

Fig. 1. Regression of daily primary productivity versus a composite variable $\left(B Z_{\mathrm{p}} I_{\mathrm{o}}\right)$ for each of the $4 \mathrm{MERL}$ experiments described in Table 1: (a) oil addition and recovery experiment, (b) sediment gradient experiment, (c) nutrient addition experiment, (d) nutrient and sludge addition experiment. ( $\Delta$ ) Points not included in analysis (see text) measured $24 \mathrm{~h}$ incubations with sequential short-term incubations over the daylight period suggested that 10 to $40 \%$ of the daytime production was respired at night (Bender et al. 1987. Keller unpubl.) for the MERL mesocosms.

Differences thus exist between the modeled daily production rates and the measured $24 \mathrm{~h}$ rates. To compare data collected during different experiments, the $24 \mathrm{~h}$ measurements were converted to daytime rates by assuming that the night-time respiration rate was $25 \%$ of the measured rate of production. For each experiment, daily productivity integrated over the photic depth $\left(P_{\mathrm{d}}, \mathrm{mg} \mathrm{C} \mathrm{m}^{-2} \mathrm{~d}^{-1}\right)$ was then regressed against the composite function $\left(B Z_{\mathrm{p}} I_{\mathrm{o}}\right)$ derived by Cole \& Cloern (1987) where $B$ is phytoplankton biomass ( $\mathrm{mg}$ chlorophyll $\left.a \mathrm{~m}^{-3}\right), Z_{p}$ the photic zone depth $(\mathrm{m})$ and $I_{\circ}$ surface irradiance (Einst. $\mathrm{m}^{-2} \mathrm{~d}^{-1}$ ).

\section{RESULTS}

\section{Composite function}

The relationship between photic zone productivity and Cole \& Cloern's (1987) composite function $B Z_{p} I_{0}$ was examined by least-squares linear regression techniques. Highly significant linear relations ( $p$
$<0.001)$ were found for all mesocosms and Narragansett Bay over the period studied (1978 to 1984). These relations were relatively consistent between the Bay controls and treatment mesocosms for the individual experiments as demonstrated by the regression parameters and their error terms (Table 2).

For each of the 4 experiments, the data from the Bay water experiments, control and treatment mesocosms were pooled and the results from the 4 experimental periods compared (Fig. 1). The intercepts and slopes for the regression equations for the 4 experiments (Table 3) were generally not significantly different at the $95 \%$ level of confidence. Despite the wide range of experimental conditions (oil addition, sediment sources, nutrient addition, sludge addition) and interannual variability, a single empirical function can be used to estimate phytoplankton production. Based on $1010{ }^{14} \mathrm{C}$ incubations, $82 \%$ of the variation in photic zone productivity was explained by the composite variable $B Z_{\mathrm{p}} I_{\mathrm{o}}$ using the equation:

$$
P_{\mathrm{d}}=220+0.70 B Z_{\mathrm{p}} I_{\mathrm{o}}
$$

\section{Biomass}

The relation between productivity integrated over the water column and phytoplankton biomass meas- 
Fig. 2. Seasonal regression of daily primary productivity versus phytoplankton biomass (measured as chlorophyll a) for (a) oil addition and recovery experiment, (b) sediment gradient experiment, (c) nutrient addition experiment, and (d) nutrient and sludge addition experiment. The $4 \times, 8 \times, 16 \times$, and $32 \times$ treatments were excluded from the non-summer regression for the nutrient addition experiment and the $8 \times$ nutrient and $8 \times$ sludge addition mesocosms were excluded from the nutrient and sludge addition experiment (summer only)

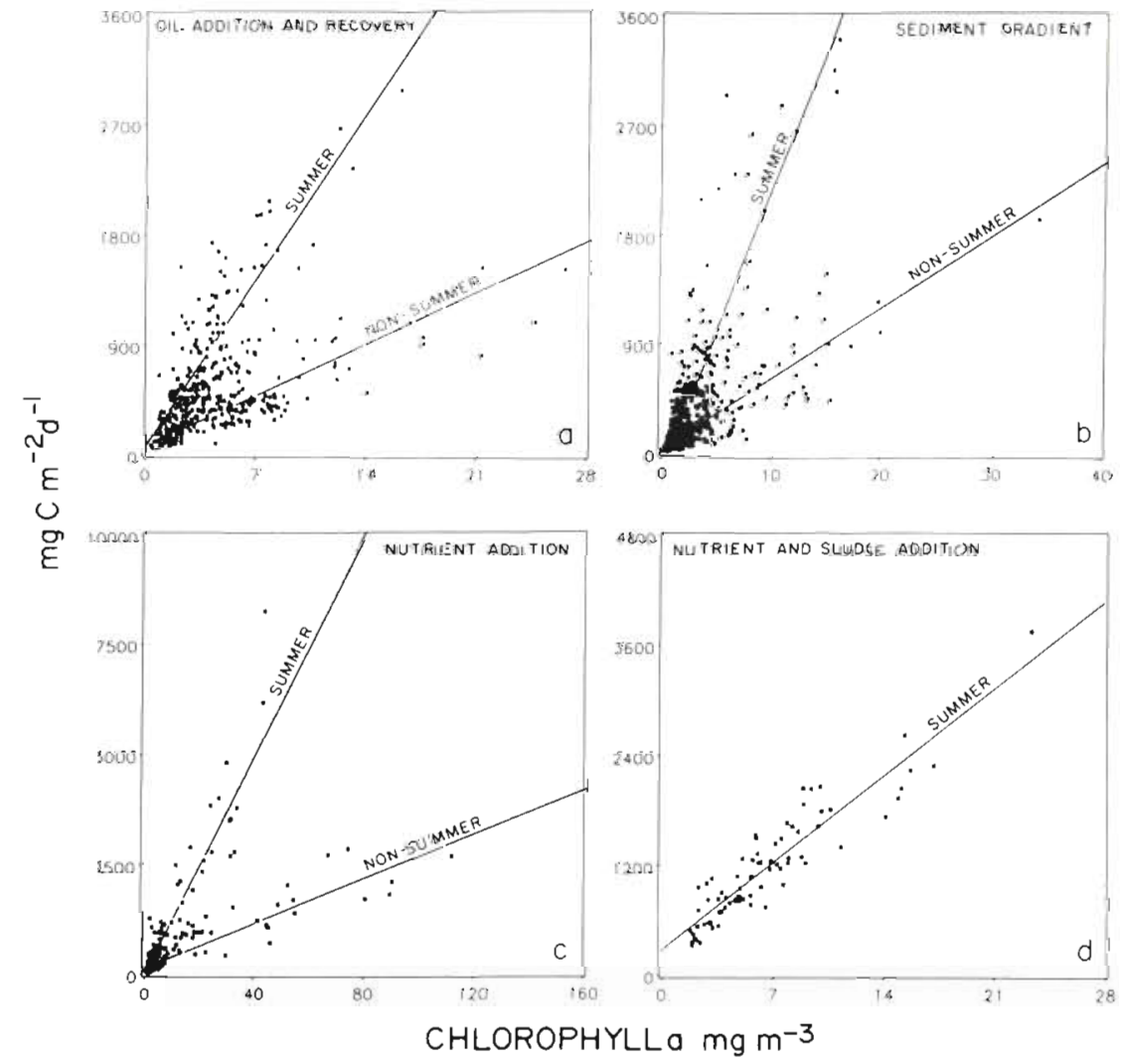

ured as chlorophyll a for experiments longer than an annual cycle revealed significant seasonal differences (Fig. 2). These differences were not evident in the data collected during the short-term (4 mo) nutrient-sludge addition experiment conducted during the summer in 1984. Subsequently, the data for the remaining 3 experiments were separated into summer (June to September) and non-summer (October to May) periods and analyzed using regression techniques.
For each experiment, individual regressions were calculated for each mesocosm and Narragansett Bay during the summer and non-summer periods (data not shown). In most cases, the seasonal regression equations for the individual mesocosms and Narragansett Bay were not significantly different within experiments. However, during the non-summer period of the nutrient addition experiment, the regression slopes for data from high level nutrient addition mesocosms $(4 \times, 8 \times, 16 \times$ and $32 \times)$

Table 4. Linear regression analyses of production $\left(P_{\mathrm{d}}, \mathrm{mg} \mathrm{C} \mathrm{m} \mathrm{m}^{-2} \mathrm{~d}^{-1}\right)$ versus phytoplankton biomass $\left(B, \mathrm{mg}_{\mathrm{chl}} \mathrm{a} \mathrm{m}^{-3}\right)$ for the individual and combined MERL experiments. Data are separated by period, with summer being June to September and nonsummer being October to May; $m$ : slope; $b$ : intercept

\begin{tabular}{|c|c|c|c|c|c|}
\hline Period & Experiment & $m( \pm \mathrm{SE})$ & $b( \pm \mathrm{SE})$ & $r^{2}$ & $n$ \\
\hline Summer & $\begin{array}{l}\text { Oil addition and recovery } \\
\text { Sediment gradient } \\
\text { Nutrient addition } \\
\text { Nutrient and sludge addition }{ }^{a} \\
\text { Pooled }^{a}\end{array}$ & $\begin{array}{ll}172.0 & (9.8) \\
196.4 & (7.9) \\
124.3 & (6.2) \\
135.1 & (6.6) \\
125.2 & (3.2)\end{array}$ & $\begin{array}{rr}192.2 & (42.7) \\
45.2 & (27.6) \\
67.3 & (85.8) \\
279.5 & (50.7) \\
253.0 & (24.4)\end{array}$ & $\begin{array}{l}0.67 \\
0.81 \\
0.82 \\
0.85 \\
0.76\end{array}$ & $\begin{array}{r}153 \\
137 \\
107 \\
77 \\
459\end{array}$ \\
\hline Non-summer & $\begin{array}{l}\text { Oil addition and recovery } \\
\text { Sediment gradient } \\
\text { Nutrient-addition } \\
\text { Pooled }^{\mathrm{b}}\end{array}$ & $\begin{array}{ll}47.4 & (2.5) \\
54.1 & (2.7) \\
53.9 & (4.0) \\
52.7 & (1.8)\end{array}$ & $\begin{array}{rr}153.1 & (15.6) \\
100.2 & (13.9) \\
24.4 & (23.9) \\
116.3 & (10.4)\end{array}$ & $\begin{array}{l}0.63 \\
0.56 \\
0.82 \\
0.60\end{array}$ & $\begin{array}{r}215 \\
311 \\
40 \\
566\end{array}$ \\
\hline
\end{tabular}


were significantly lower than the controls and low level nutrient treatments $(1 x$ and $2 x)$. Also, during the nutrient-sludge addition experiment (summer only) the slopes of the regressions between productivity and chlorophyll $a$ in the $8 \times$ nutrient and $8 \times$ sludge treatments were significantly lower than the other treatments.

After excluding the noted exceptions, for each experiment the data from the individual mesocosms and the Bay were pooled and analyzed seasonally (Table 4). There was a distinct seasonal shift in the productivityto-biomass relation with the slope of the regression equations significantly higher in the summer than the non-summer period. A single regression was developed for each period (summer versus non-summer). During the summer, chlorophyll a accounted for $76 \%$ of the variation in primary productivity, while during the nonsummer period $60 \%$ of the variation in productivity could be explained as a function of biomass (Table 4).

\section{Annual production}

Yearly primary production $\left(P_{y}, \mathrm{~g} \mathrm{C} \mathrm{m}^{-2} \mathrm{yr}^{-1}\right)$ was calculated by integrating the measured production values over an annual cycle. Estimates of annual productivity in the control mesocosms and GSO Dock station in Narragansett Bay varied by a factor of 2 within years (Table 5). Between years, annual productivity in these systems varied by a factor of 3 , ranging from a low of $82 \mathrm{~g} \mathrm{C} \mathrm{m}^{-2} \mathrm{yr}^{-1}$ to a high of $273 \mathrm{~g} \mathrm{C} \mathrm{m}^{-2} \mathrm{yr}^{-1}$. Estimated productivity in the control tanks and Bay averaged $155 \mathrm{~g} \mathrm{C} \mathrm{m}^{-2} \mathrm{yr}^{-1}$ for the 1978 to 1983 period.

Yearly productivity $\left(P_{y}\right)$ was regressed against annual mean values of $B Z_{\mathrm{p}} I_{\mathrm{o}}$ for the mesocosms and the Bay over the 1978 to 1983 period (Fig. 3). The resulting equation:

$$
P_{\mathrm{y}}=25( \pm 10)+0.30( \pm 0.02)
$$

with $n=32$ was highly significant $(p<0.001)$ and accounted for $92 \%$ of the variation in annual production. The values in parentheses are the standard errors for the regression parameters.

\section{DISCUSSION}

\section{Composite factor}

Cole \& Cloern (1987) demonstrated a strong linear correlation between integral productivity and $B Z_{p} I_{0}$ for 7 estuarine regions. Similarly good correlations between phytoplankton productivity and biomass coupled with light availability were reported by Falkowski (1981) and Cole \& Cloern (1984). The general applicability of this relationship was confirmed here using an

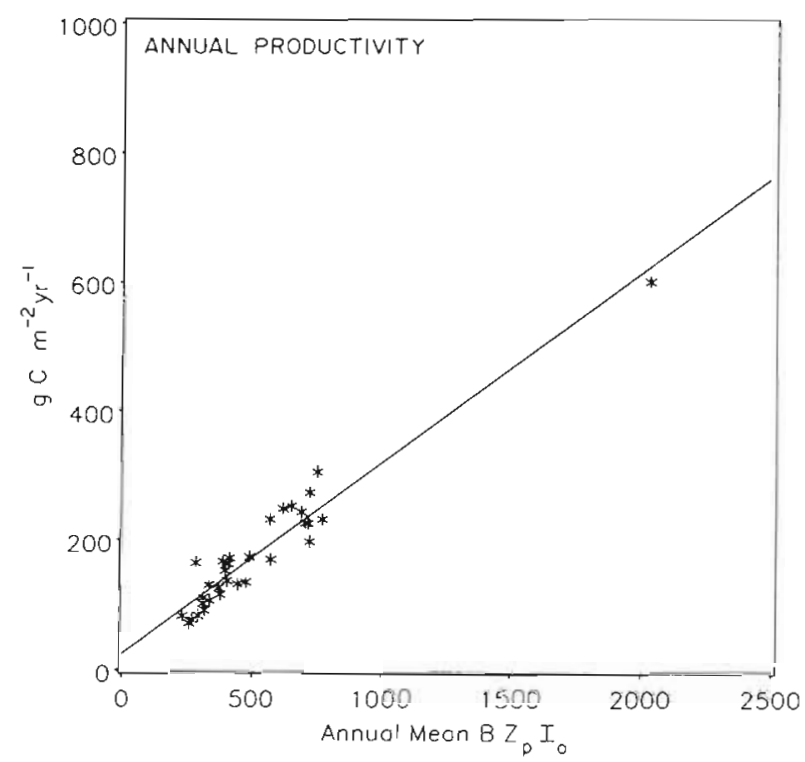

Fig. 3. Annual water column productivity plotted as a function of mean annual $B Z_{\mathrm{p}} I_{\circ}$ for the MERL mesocosms and Narragansett Bay (GSO Dock Station). The annual periods are listed in Table 5

extensive data set from Narragansett Bay and the MERL experimental ecosystems. For the wide range of experimental conditions encountered over the study period, the slopes of the equations relating productivity to $B Z_{\mathrm{p}} I_{\mathrm{o}}$ varied remarkably little $(0.66$ to 1.04$)$ and did not differ seasonally (summer versus non-summer). Cole \& Cloern (1987), using data with similar units of

Table 5. Annual productivity $\left(P_{y}, g \mathrm{C} \mathrm{m}^{-2} \mathrm{yr}^{-1}\right)$ for the control mesocosms and Narragansett Bay (GSO Dock Station). Numbers in parentheses are Julian dates (e.g. $78045=$ Day 45 of 1978)

\begin{tabular}{|c|c|c|c|c|}
\hline Tank & $\begin{array}{c}1978 \\
(78045-79044)\end{array}$ & $\begin{array}{c}1979 \\
(79001-79365)\end{array}$ & $\begin{array}{c}1980 \\
(80001-80365)\end{array}$ & $\begin{array}{c}1982-83 \\
(82181-83180)\end{array}$ \\
\hline 1 & 134 & 173 & 110 & $82^{a}$ \\
\hline 5 & 273 & 231 & 82 & 121 \\
\hline 8 & 131 & 166 & 162 & 121 \\
\hline Bay & 250 & 164 & 152 & 98 \\
\hline Tank 0 & & & & \\
\hline
\end{tabular}


measurement, reported a range in slope of 0.67 to 1.14 for 4 independent studies while Platt (1986) found a similarly small range in slope for the regression of biomass specific productivity on $I_{0}$ over a wide range of oceanic waters. Frequently, the intercepts of these equations are not significantly different from 0 .

In the above cases, greater than $80 \%$ of the variability in productivity was commonly explained by variation in the composite parameter. The consistency of these results confirms that much of the large-scale variation in productivity in nutrient-rich estuaries can be explained as a function of phytoplankton biomass and light availability.

\section{Incubation length}

The principal problem encountered in considering the mesocosm experiments as a single data set was adjusting $24 \mathrm{~h}{ }^{14} \mathrm{C}$ incubations to approximate daytime measurements derived from $4 \mathrm{~h}$ incubations. The $4 \mathrm{~h}$ incubations used for the model were considered to estimate gross daytime productivity (Davies \& Williams 1984, Harrison et al. 1985, Bower et al. 1987) since not much respiratory loss of fixed ${ }^{14} \mathrm{C}$ occurs until the dark period.

Cole \& Cloern (1987) included both $24 \mathrm{~h}{ }^{14} \mathrm{C}$ incubations and half-day (noon to sunset) incubations in their composite data set. They made no attempt to account for night-time respiration. However, their Fig. 2 suggested that the half-day incubations (adjusted by a factor of 2 to give daytime measurements) from Puget Sound are important in controlling the slope of the final regression equation for the assembled data set. For comparison with their equation, I adjusted the $24 \mathrm{~h}$ values to daytime production measurements rather than vice versa. Their final equation for 211 incubation experiments using pooled data from San Francisco Bay, Puget Sound and the Hudson River Plume:

$$
P=150+0.73 B Z_{\mathrm{p}} I_{0}
$$

is very similar to the final equation for pooled data over all experiments $(N=1010)$ seen in the above analysis (Table 3). When no adjustments are made for respiration, the slope of the mesocosm regression for $24 \mathrm{~h}$ production versus $B Z_{p} I_{0}$ is lower $(0.63 \pm 0.03)$. Thus the length of the ${ }^{14} \mathrm{C}$ incubation should be considered in comparing the results since daytime measurements may approximate gross primary production while $24 \mathrm{~h}$ measurements may be closer to net (Peterson 1980).

\section{Model considerations}

Given the wide range of experimental conditions, the close agreement in regression equations emphasizes the general applicability of this empirical approach to predicting productivity in other estuaries with similar properties and behavior. As suggested by Cole \& Cloern (1987) the technique will allow increased temporal and spatial coverage of productivity in diverse estuarine systems. After calibration by a few measures of productivity, large-scale surveys of the more readily measured chlorophyll a and light availability should improve our knowledge of productivity throughout an estuary.

In all experiments, a few data points deviated widely from the observed relation (Fig. 1). Although these points are shown in the figures they were not included in the regression analysis. During the nutrient addition experiment (Fig. 2C), abnormally low levels of measured versus predicted productivity were confined to the higher level $(16 \times$ and $32 \times)$ treatment mesocosms. Nutrient limitation was not a problem in these measurements. The low productivity was traced to dense algal growth on the outside of incubation bottles lowering light availability. In other instances over- or underprediction of productivity might be measurement error, nutrient limitation, toxicity effects or high assimilation rates. Deviations from predicted values might indicate when factors other than biomass and light are important in controlling productivity (Cole \& Cloern 1987).

Table 6. Annual primary productivity $\left(P_{\mathrm{y}}, \mathrm{g} \mathrm{C} \mathrm{m}^{-2} \mathrm{yr}^{-1}\right)$ for selected estuaries and coastal regions of the USA

\begin{tabular}{|llcl|}
\hline Area & & $P_{y}$ & \multicolumn{1}{c|}{ Source } \\
\hline \multirow{2}{*}{ Narragansett Bay } & Mid-Bay & 308 & Furnas et al. 1976 \\
& GSO Dock & 221 & Oviatt et al. 1981 \\
& GSO Dock & 189 & This study \\
Hudson Estuary & Bight & 370 & Malone 1976 \\
& Lower Bay & 200 & Malone 1977 \\
Chesapeake Bay & Mid-Bay & $335-780$ & Boynton et al. 1982 \\
Delaware Bay & & $190-400$ & Pennock \& Sharp 1986 \\
San Francisco Bay & & $95-150$ & Cole \& Cloern 1984 \\
\hline
\end{tabular}




\section{Biomass}

For the MERL mesocosms and Narragansett Bay, the relationship between primary productivity and chlorophyll a alone showed a marked seasonal difference. Productivity and chlorophyll $a$ were significantly correlated $(p<0.01)$ during both summer $(r=0.87)$ and non-summer $(r=0.77)$ periods. For each experiment, and overall, chlorophyll-specific production rate (slope of the regression line) was significantly higher during the summer compared with the non-summer period by a factor of ca 2.5 .

Chlorophyll a has been considered a poor indicator of phytoplankton productivity over a wide range of environmental conditions or aquatic environments (Cadée \& Hegeman 1974, Boynton et al. 1982, Cole \& Cloern 1984, Côté \& Platt 1984). And yet, within specific embayments in San Francisco Bay, Cole \& Cloern (1984) found good correlations ( $r=0.53$ to 0.92) between production and chlorophyll a. Malone et al. (1986) reported similarly high correlations ( $r=0.97$ to 0.98 ) for distinct geographic areas within Chesapeake Bay. Côté \& Platt (1983) noted shifts in the relation between maximum phytoplankton production rates and chlorophyll a which correlated with major changes in phytoplankton species composition. Pennock \& Sharp (1986) showed a marked seasonal change in the relation between productivity and a variable composed of biomass and light availability, with the slope of the relation being greater during the summer. They attributed this shift to either periodic nutrient limitation, zooplankton grazing or changes in species composition from diatoms to nanoplankton.

In the mesocosms and Narragansett Bay, the increase in the slope of the equation relating primary productivity to biomass corresponded with the change in species composition from net plankton (primarily diatoms) to nanoplankton (primarily flagellates) (Pratt 1959, Durbin et al. 1975. Furnas et al. 1976). In Narragansett Bay, the nanoplankton $(<20 \mu \mathrm{m})$ are most important during the summer when over $75 \%$ of the chlorophyll a is in this size class (Durbin et al. 1975). During this period the productivity-to-chlorophyll a ratios (slope of regression, Table 4) were significantly higher than the non-summer periods when net plankton dominate. These results, thus, support the basic hypothesis that small cells have higher rates of productivity per unit chlorophyll a than do large cells.

Durbin et al. (1975) suggest that dominance of nanoplankton during the summer in Narragansett Bay is favored by the high temperatures and low nutrient levels present at that time, while Furnas et al. (1976) suggest that the summer phytoplankton dynamics in the Bay are primarily influenced by nutrient regulation and grazing. The data presented here show a signifi- cant increase in the productivity-to-chlorophyll a ratio during the summer when nanoplankton predominate. There was no significant difference in the production to $B Z_{p} I_{0}$ relationship on a seasonal basis. Since the average photic depths were greater in the summer than the non-summer periods, the higher slope for the nanoplankton-dominated community might be due to increased ambient light level.

Bruno et al. (1983) found no significant differences for productivity per unit chlorophyll a between net plankton and nanoplankton fractions during periods of clear dominance of either size fraction. They noted, however, that their net plankton could really be considered nanoplankton if chain length were ignored. Malone (1980) indicated that both high temperature and light were important in the observed seasonal differences in production efficiencies between size fractions in estuaries during summer. The mesocosm and Bay data suggest that high ambient light is a major factor controlling the production to biomass ratio $(P: B)$ for summer phytoplankton (primarily nanoplankton) populations. However, the importance of temperature in controlling $P: B$ cannot be ruled out since temperature and light were significantly correlated $(r=0.59, p$ $<0.001$ ) on an annual basis.

Twice, regressions from individual mesocosms had slopes which were significantly lower than expected relative to the overall seasonal regressions (Table 4). In both cases these were high nutrient concentration or sludge treatment tanks. As noted previously, low rates of primary production were occasionally found in mesocosms with high nutrient concentrations, and are believed to be due to shading caused by algal growth on the outside of the incubation bottles. The phytoplankton in these mesocosms may have had changes in their size and/or species composition. Sanders et al. (1987) reported large changes in dominant phytoplankton species and patterns of succession during nutrient enrichment experiments in the Patuxent River, Chesapeake Bay, USA. They concluded that nutrient enrichment promoted diatom dominance particularly during the summer and early fall.

No increase in total diatom abundance (in the $>10 \mu \mathrm{m}$ size fraction) was noted in the upper level sludge and nutrient treatment tanks during summer 1984 (Keller 1987b). However, these mesocosms had higher abundances of dinoflagellates than the controls and lower level treatments (Keller 1987b). In the highest level nutrient treatment tank $32 \%$ of phytoplankton biomass (measured as in vivo fluorescence) was in the $>10 \mu \mathrm{m}$ size fraction compared with $18 \%$ in mesocosms with low nutrient concentrations. The alterations in species composition and size distribution, away from the expected summer dominance by small phytoplankton (Durbin et al. 1975) with high productivity (Furnas et al. 
1976), may thus explain the observed decrease in chlorophyll a specific production rates in these upper level treatment mesocosms.

\section{Annual productivity}

The range in annual productivity (Table 5) for the control mesocosms and Narragansett Bay is at the midto lower range of values reported for other estuaries (Table 6) but represents a single location in lower Narragansett Bay. Furnas et al. (1976) estimated annual productivity for a mid-Narragansett Bay station as $308 \mathrm{~g} \mathrm{C} \mathrm{m}^{-2} \mathrm{yr}^{-1}$. Oviatt et al. (1981) noted a decreasing down-Bay gradient in primary productivity with the lowest values in the West Passage of Narragansett Bay at the GSO Dock station.

Annual values of productivity for the mesocosms and Bay during the experimental period (1978 to 1983) were highly correlated with mean annual values of $B Z_{\mathrm{p}} I_{0}$. Smayda (1983) attributed variation in productivity between years to variation in insolation. The data presented here demonstrate that variability in annual productivity is due not only to light but also to annual variations in the mean values of biomass and photic zone depth. Mean annual $B Z_{\mathrm{p}} I_{0}$ may prove useful for estimating annual productivity, with a minimum expenditure of effort, for estuarine systems.

In summary, the mesocosm results and Narragansett Bay data lend considerable support to the empirical model proposed by Cole \& Cloern (1987) for predicting primary productivity in estuaries. The success of the approach is tied to the indirect incorporation of nutrient loading, growth rate, grazing rate, sinking and many associated processes in the model through biomass combined with the importance of light availability in controlling productivity in these turbid environments. The relationship was consistent over the annual cycle. On a seasonal basis, production was seen to be highly correlated with biomass alone measured as chlorophyll a concentration. The decline in chlorophyll-specific production rate during the non-summer period coincided with the switch in predominance from primarily nanoplankton (flagellates) during the summer to primary net plankton (diatoms) during the rest of the year and also coincided with decreased irradiance. Annual levels of primary productivity in the control mesocosms and lower Narragansett Bay were comparable and at the mid to lower range of values reported for other estuarine systems. Yearly production for all mesocosms and the Bay was highly correlated $(p<0.001)$ with mean annual $B Z_{\mathrm{p}} I_{\mathrm{o}}$.

Acknowledgements. I gratefully acknowledge Glenn Almquist, Steve Kelly, Nancy Craig, Lynn Beatty and all of the MERL staff, graduate students and scientists who participated in the various experiments. Special thanks are also extended to Candace Oviatt (Chief Scientist), Eric Klos (Facility Manager), and Marge Cook (secretary) for their assistance and support throughout this project. This study was supported by EPA grants R 803902020, 806072010, 806072020, EPA Cooperative Agreements CR807795-01, 8077950-02, 81026501, 810265-03 and NOAA Grant NA-83-ABD-00008.

\section{LITERATURE CITED}

Almquist, G. $\mathrm{T}$ (1983). ${ }^{14} \mathrm{C}$ estimation of primary production In: Lambert, C. E., Oviatt, C. A. (eds.) Manual of biological and geochemical techniques in coastal areas. MERL Series Report No. 1, University of Rhode Island, Kingston, Rhode Island, p. 14-19

Bender, M., Grande, K., Johnson, K., Marra, J., Williams, P. J leB., Sieburth, J., Pilson, M., Langdon, C., Hitchock, G., Orchardo, J., Hunt, C., Donaghay, P., Heinemann, K. (1987). A comparison of four methods for the determination of planktonic community metabolism. Limnol. Oceanogr 32 (5): 1085-1098

Bower, P. M., Kelly, C. A., Fee, E. J., Shrearer, A., DeClercq, R. Schindler, W. (1987). Simultaneous measurement of primary production by whole-lake and bottle radiocarbon additions. Limnol. Oceanogr. 32 (2): 299-312

Boynton, W. R., Kemp, W. M., Keefe, C. W. (1982). A comparative analysis of nutrients and other factors influencing estuarine phytoplankton production. In: Kennedy, $\mathrm{V}$ S. (ed.) Estuarine comparisons. Academic Press, New York, p. $69-90$

Bruno, S. F., Staker, R. D., Sharma, G. M., Turner, J. T. (1983) Primary productivity and phytoplankton size fraction dominance in a temperate North Atlantic estuary. Estuaries 6: 200-211

Cadée, G. C. (1978). Primary production and chlorophyll in the Zaire River, estuary and plume. Neth. J. Sea Res. 12: 368-381

Cadée, G. C., Hegeman, J. (1974). Primary production of phytoplankton in the Dutch Wadden Sea. Neth. J. Sea Res. 8: $240-259$

Cole, B. E., Cloern, J. E. (1984). Significance of biomass and light availability to phytoplankton productivity in San Francisco Bay. Mar. Ecol. Prog. Ser. 17: 15-24

Cole, B. E., Cloern, J. E. (1987). An empirical model for estimating phytoplankton productivity in estuaries. Mar. Ecol. Prog. Ser. 36: 299-305

Côté, B., Platt, T. (1983). Day-to-day variations in the springsummer photosynthetic parameters of coastal marine phytoplankton. Limnol. Oceanogr. 28 (2): 320-344

Côté, B., Platt, T. (1984). Utility of the light saturation curve as an operational model for quantifying the effects of environmental conditions on phytoplankton photosynthesis. Mar. Ecol. Prog. Ser. 18: 57-66

Davies, J. M., Williams, P. J. leB. (1984). Verification of ${ }^{14} \mathrm{C}$ and $\mathrm{O}_{2}$ derived primary organic production measurements using an enclosed ecosystem. J. Plankton Res. 6 (3): $457-474$

Durbin, E. G., Krawiec, R. W., Smayda, T. J. (1975). Seasonal studies on the relative importance of different size fractions of phytoplankton in Narragansett Bay (USA). Mar. Biol. 32: 271-287

Falkowski, P. G. (1981). Light-shade adaptation and assimilation numbers. J. Plankton Res. 3: 203-216

Flemer, D. (1970). Primary production in Chesapeake Bay. Chesapeake Sci. 11: 117-129 
Furnas, M. J., Hitchcock, G. L., Smayda, T. J. (1976). Nutrientphytoplankton relationships in Narragansett Bay during the 1974 summer bloom. Estuarine Processes 1: 119-133

Harding, L. W., Meeson, B. W., Fisher, T R. (1986). Phytoplankton production in two east coast estuaries: photosynthesis - light functions and patterns of carbon assimilation in Chesapeake and Delaware Bays. Estuar. coast. Shelf Sci. 23: 773-806

Harrison, W. G., Platt, T., Lewis, M. R. (1985). The utility of light-saturation models for estimating marine primary productivity in the field: a comparison with conventional 'simulated' in situ methods. Can. J. Fish. Aquat. Sci. 42: $864-872$

Joint, I. R., Pomroy, A. J. (1981). Primary production in a turbid estuary. Estuar. coast. Shelf Sci. 13: 303-316

Keller, A. A. (1986). Modeling the productivity of natural phytoplankton populations using mesocosm data along a nutrient gradient. Ph. D. dissertation, University of Rhode Island, Kingston, Rhode Island

Keller, A. A. (1987a). Modeling and forecasting primary production rates using Box-Jenkins transfer function models Can. J. Fish. Aquat. Sci. 44: 1045-1052

Keller, A. A. (1987b). Mesocosm studies of DCMU-enhanced fluorescence as a measure of phytoplankton photosynthesis. Mar. Biol. 96: 107-114

Malone, T. C. (1976). Phytoplankton productivity in the apex of the New York Bight: environmental regulation of productivity/chlorophyll a. In: Gross, M. G. (ed.) The middle Atlantic shelf and New York Bight. Limnol. Oceanogr., Spec. Symp., Vol 2: 260-272

Malone, T C. (1980). Size-fractionated primary productivity of marine phytoplankton. In: Falkowski, P. G. (ed.) Primary productivity in the sea. Plenum Press, New York, p. 301-319

Malone, T. C., Kemp, W. M., Ducklow, H. W., Boynton, W. R., Tuttle, J. H., Jonas, R. B. (1986). Lateral variation in the production and fate of phytoplankton in a partially stratified estuary. Mar. Ecol. Prog. Ser. 32: 149-160

Nixon, S. W., Oviatt, C. A., Frithsen, J., Sullivan, B. (1986). Nutrients and the productivity of estuarine and coastal ecosystems. J. Limnol. Soc. Sth Afr 12 (V2): 43-71

Nixon, S. W., Pilson, M. E. Q. (1983). Nitrogen in estuarine and coastal marine ecosystems. In: Carpenter, E. J., Capone, D. G. (eds.) Nitrogen in the marine environment. Academic Press, New York, p. 565-648

Nixon, S. W., Pilson, M. E. Q., Oviatt, C. A., Donaghay, P., Sullivan, B., Seitzinger, S., Rudnick, D., Frithsen, J. (1984). Eutrophication of a coastal marine ecosystem - an experimental study using the MERL microcosms. In: Fasham, M. J. R. (ed.) Flows of energy and material in marine ecosystems. Plenum Press, New York, p. 105-135

Oviatt, C. A., Buckley, B., Nixon, S. W. (1981). Annual phytoplankton metabolism in Narragansett Bay calculated from survey field measurements and microcosm observations Estuaries 4 (3): $16 \overline{7}-175$

Oviatt, C. A., Frithsen, J., Gearing, J., Gearing, P. (1982). Low chronic additions of no. 2 fuel oil: chemical behavior, biological impact and recovery in a simulated estuarine environment. Mar Ecol. Prog. Ser. 9: 121-136

Oviatt, C. A., Keller, A. A., Sampou, P. A., Beatty, L. L. (1986). Patterns of productivity during eutrophication: a mesocosm experiment. Mar. Ecol. Prog. Ser. 28: 69-80

Oviatt, C., Pilson, M. E. Q., Nixon, S., Frithsen, J., Rudnick, D T., Kelly, J. R., Grassle, J. F., Grassle, J. P. (1984). Recovery of a polluted estuarine system: a mesocosm experiment. Mar. Ecol. Prog. Ser. 16: 203-217

Oviatt, C. A., Quimn, J. G., Maughan, J. T., Ellis, J. T., Sullivan, B. K., Gearing, J. N., Gearing, P. J., Hunt, C. D., Sampou, P. A., Latimer, J. S. (1987). Fate and effects of sewage sludge in the coastal marine environment: a mesocosm experiment. Mar. Ecol. Prog. Ser. 41: 187-203

Pennock, J. R., Sharp, J. H. (1986). Phytoplankton production in the Delaware Estuary: temporal and spatial variability. Mar. Ecol. Prog. Ser. 34: 143-155

Peterson, B. J. (1980). Aquatic primary productivity and the ${ }^{14} \mathrm{C}-\mathrm{CO}_{2}$ method: a bistory of the productivity problem. Ann. Rev. Ecol. Syst. 11: 359-385

Pilson, M. E. Q., Oviatt, C. A., Vargo, G. A., Vargo, S. L. (1979). Replicability of MERL microcosms: initial observations. In: Jacoff, F. S. (ed.). Advances in marine environmental research. Symp. Proc. June 1977, EPA-600/9-79035, Environmental Protection Agency, Narragansett Rhode Island, p. 361-383

Platt, T., Jassby, A. D. (1976). The relationship between photosynthesis and light for natural assemblages of coastal marine phytoplankton. J. Phycol. 12: 421-430

Platt, T. (1986). Primary production of the ocean water column as a function of surface light intensity: algorithms for remote sensing. Deep Sea Res. 31: 1-11

Pratt, D. (1959). The phytoplankton of Narragansett Bay. Limnol. Oceanogr. 4: 425-440

Riley, G. A. (1967). The plankton of estuaries. In: Lauff, G. A (ed.) Estuaries. Publ. Am. Ass. Advmt Sci., Wash., D. C., p $316-328$

Sanders, J. G., Cibik, S. J., D'Elia, C. F., Boynton, W. R. (1987) Nutrient enrichment studies in a coastal plain estuary changes in phytoplankton species composition. Can. J Fish. Aquat. Sci. 44: 83-90

Smayda, T J. (1983). The phytoplankton of estuaries. In Ketchum, B. H. (ed.) Estuaries and enclosed seas. EIsevier Scientific Publish. Co., Amsterdam, p. 65-102

Strickland, J. D. H., Parsons, T. R. (1972). A practical handbook of seawater analysis. Bull. Fish. Res. Bd Can. 167: pp. 311

Takahashi, M., Fujii, K., Parsons, T R. (1973). Simulation study of phytoplankton photosynthesis and growth in the Fraser River Estuary. Mar. Biol. 19: 102-116 